\title{
Implementasi Pembinaan Kepramukaan Terhadap Persepsi Kepala Sekolah Di SMP Se-Kecamatan Baiturrahman Banda Aceh
}

\author{
Edi Azwar \\ Fakultas keguruan dan Ilmu Pendidikan Universitas Serambi Mekkah \\ Email.edi.azwar@serambimekkah.ac.id
}

\begin{abstract}
Abstrak
Penelitian ini bertujuan untuk mengetahui Implementasi Pembinaan Kepramukaan Terhadap Persepsi Kepala Sekolah Di SMP Se-Kecamatan Baiturrahman Banda Aceh tahun 2016. Keberhasilan pembinaan pramuka di SMP se-Kecamatan Baiturrahman Banda Aceh tahun 2016 dapat dilihat dari berbagai prestasi dalam bidang kepramukaan. Dari tahun ke tahun, beragam kejuaran berhasil diraih. Dengan demikian, pembinaan kegiatan pramuka di SMP se-Kecamatan Baiturrahman Banda Aceh tahun 2016 te rutama dalam kegiatan rutin kepramukaan, dapat dikatakan telah berhasil. Hal tersebut dapat dibuktikan dari hasil keseluruhan jawaban angket tertutup dengan kepala sekolah di SMP se-Kecamatan Baiturrahman Banda Aceh yang berada pada rata-rata 3,44 dengan persentase sangat setuju yaitu 57,33\%, sehingga dapat dikatakan bahwa pembinaan kegiatan kepramukaan di SMP se-Kecamatan Baiturrahman Banda Aceh Tahun 2016 berlangsung dengan baik.
\end{abstract}

\section{PENDAHULUAN}

Pendidikan kepramukaan merupakan kegiatan ekstrakurikuler yang secara sistemik diperankan sebagai wahana penguatan psikologis, social, kultural (reinfocement) perwujudan sikap dan keterampilan kurikulum 2013 yang secara psikopedagogis koheren dengan pengembangan sikap dan kecakapan dalam pendidikan kepramukaan. Selain itu, pendidikan kepramukaan merupakan subsistem Pendidikan Nasional yang mempunyai peranan penting bagi terwujudnya tujuan Pendidikan Nasional sebagaimana yang tercantum dalam UU RI No.20 tahun 2003 tentang sistem Pendidikan Nasional, yaitu "Kegiatan pramuka sebagai kegiatan ekstrakurikuler dapat dijadikan sebagai salah satu aktivitas yang dapat mendukung proses pembelajaran di sekolah. Oleh karena itu kegiatan pramuka ada hubungannya antara proses kehidupan mengingat manusia adalah makhuk sosial dimana manusia tidak dapat hidup sendiri melainkan membutuhkan partisipasi orang lain".

Pada hakikatnya, pendidikan kepramukaan adalah proses pendidikan di luar lingkungan sekolah dan di luar lingkungan keluarga dalam bentuk kegiatan yang menarik, menyenangkan, sehat, teratur, terarah dan dilakukan di alam terbuka (Agus Widodo, 2003:73). Gerakan pramuka adalah gerakan pendidikan kaum muda yang menyelenggarakan kepramukaan dengan dukungan dan bimbingan anggota dewasa sebagai gerakan pendidikan, usaha gerakan pramuka tidak lepas dari pola dasar pendidikan nasional dan merupakan salah satu sarana pendidikan, di samping sarana pendidikan yang lain (keluarga, sekolah, kelompok sebaya, lingkungan kerja dan masyarakat) (Zainal Aqib \& Sujak, 2011: 81).

Kegiatan ekstrakurikuler Kepramukaan merupakan salah satu wujud dalam mencapai tujuan sekolah, dan dalam pelaksanaannya dikoordinasikan sekolah di bawah 
kepemimpinan kepala sekolah dan dibimbing oleh guru maupun tenaga yang dikelola sekolah yang disebut pembina Pramuka. Wahyudi (2009:73) menegaskan agar terbinanya hubungan kerjasama yang baik antara kepala sekolah dan guru maka tujuan sekolah dapat tercapai dengan mudah.

Hubungan kerjasama tersebut harus dibangun dengan berlandaskan kepemimpinan kepala sekolah yang berlangsung secara dinamis dan bersahaja sehingga mampu mendapatkan apresiasi dikalangan siswa. Siswa mengenal dan memahami nilai kemandirian sebagaimana dikembangkan melalui Kode Kehormatan Satya dan Darma Pramuka.

\section{TINJAUAN PUSTAKA \\ Kepala Sekolah}

Kepala Sekolah merupakan organisasi yang kompleks dan unik, organisasi yang kompleks karena di dalam sekolah terdapat sumber daya-sumber daya yang saling terkait, sedangkan sebagai organisasi yang unik karena sekolah menjadi tempat proses belajar-mengajar dan pembudaya kehidupan umat manusia (Wahjosumidjo, 2005:81). Untuk dapat mencapai tujuan sekolah, diperlukan pemimpin yang mampu mendayagunakan sumber daya-sumber daya tersebut agar dapat dimanfaatkan semaksimal mungkin untuk mencapai tujuan yang telah ditetapkan, tanpa seorang pemimpin sekolah tidak akan bisa berhasil. Pendapat tersebut dipertegas oleh Gibson (Sudarwan Danim, 2004: 145), yang mengemukakan bahwa keberhasilan sekolah banyak ditentukan oleh kapasitas kepala sekolahnya di samping adanya guru-guru yang kompeten di sekolah itu. Dengan demikian keberadaan kepala sekolah sangat penting dalam menentukan keberhasilan sekolah.

\section{Pramuka}

Pramuka adalah singkatan dari Praja Muda Karana, yang artinya orang-orang berjiwa muda dan suka berkarya. Pramuka adalah salah satu kegiatan ekstrakurikuler yang wajib diikuti oleh siswa sekolah. Donowardojo, LS dan M. Jauhari (2005:1) mengatakan bahwa Pramuka memiliki tingkatan yang didasarkan pada umur siswa, yaitu Siaga (bagi siswa yang berumur antara 7-10 tahun), Penggalang (bagi siswa yang berumur antara 11-15 tahun), Penegak (bagi siswa yang berumur 18-20 tahun), dan Pandega (bagi siswa yang berumur 21-25 tahun).

Menurut UU No. 12 Tahun 2010 Pasal 1 ayat 2, Pramuka adalah warga negara Indonesia yang aktif dalam pendidikan kepramukaan serta mengamalkan Satya Pramuka dan Darma Pramuka (Tim Kwartir Daerah XII Gerpram DIY, 2010:2).

\section{METODE PENELITIAN \\ Rancangan penelitian}

Rancangan penelitian yaitu mengambil teknih Total sampling yaitu dengan mengambil keseluruhan populasi untuk dijadikan sampel penelitian yaitu kepala sekolah yang berasal dari SMP se-Kecamatan Baiturrahman yang berjumlah 6 orang kepala sekolah.

\section{Tempat dan Waktu Penelitian}


Penelitian ini akan dilaksanakan di SMP se-Kecamatan Baiturrahman Banda Aceh, yaitu di SMP Negeri 16, SMP Negeri 17, SMP Negeri 3, SMP Budi Dharma, SMP Cut Meutia, dan SMP Kartika XIV.

\section{Analisis Data}

Teknik pengolahan data yang digunakan dalam penelitian ini adalah bersifat kuantitaif yaitu menggunakan rumus-rumus statistic. Moleong, 2004 : 248, mengemukakan bahwa "analisis data kuantitatif adalah upaya yang dilakukan dengan jalan bekerja dengan data, mengorganisasikan data, memilih-milihnya menjadi satuan yang dapat dikelola, mensintesiskannya, mencari dan menemukan pola, menemukan apa yang penting dan apa yang dipelajari, dan memutuskan apa yang dapat diceritakan kepada orang lain". Menghitung persentase dengan menggunakan rumus sebagai berikut:

$$
\begin{aligned}
P=\frac{f}{N} \times 100 \% & \\
\text { Ketrangan : } & \\
\mathrm{P} & =\text { Angka persentase } \\
\mathrm{f} & =\text { Frekwensi } \\
\mathrm{N} & =\text { Jumlah frekwensi banyaknya responden (Hadi, 1992:67) }
\end{aligned}
$$

\section{HASIL PENELITIAN DAN PEMBAHASAN}

Data yang telah di peroleh melalui angket tentang Implementasi Pembinaan Kepramukaan Terhadap Persepsi Kepala Sekolah Di SMP Se-Kecamatan Baiturrahman Banda Aceh tahun 2016 selanjutnya akan di lakukan penafsiran. Adapun langkahlangkah yang ditempuh adalah menghitung persentase $(\%)$ setiap alternative jawaban yang diperoleh dan membuat tabel serta menafsirkannya.

Berdasarkan hasil penelitian menunjukan bahwa 50,00\% atau disebut setengah dari jawaban sampel sangat setuju dengan keterampilan khusus yang dimilki oleh anggota pramuka yang tidak dimiliki oleh peserta didik yang lain dan setengahnya lagi atau 50,00\% menjawab setuju dengan pernyataan tersebut. 66,67\% atau disebut sebagian besar dari jawaban sampel sangat setuju dengan kegiatan lain yang diikuti oleh anggota pramuka di sekolah dan 33,33\% atau disebut sebagian kecil menjawab setuju dengan pernyataan tersebut. Menunjukan bahwa 50,00\% atau disebut setengah dari jawaban sampel sangat setuju dengan kelengkapan fasilitas kepramukaan di sekolah dan setengahnya lagi atau 50,00\% menjawab setuju dengan pernyataan tersebut.

Berdasarkan hasil penelitian menunjukan bahwa 50,00\% atau disebut setengah dari jawaban sampel sangat setuju dengan dukungan yang harus diberikan kepada anggota pramukaan di setiap sekolah dalam mengikuti berbagi kegiatan kepramukaan dan setengahnya lagi atau 50,00\% menjawab setuju dengan pernyataan tersebut. $66,67 \%$ atau disebut sebagian besar dari jawaban sampel sangat setuju dengan kegiatan kepramukaan yang diikuti oleh anggota pramuka di sekolah sangat menyenangkan dan $33,33 \%$ atau disebut sebagian kecil menjawab setuju dengan pernyataan tersebut. Menunjukan bahwa 100\% atau disebut seluruhnya dari jawaban sampel sangat setuju dengan kegiatan kepramukaan yang diikuti oleh anggota pramuka di sekolah mampu menyalurkan berbagai ide- ide yang bagus pada setiap anggotanya.

Berdasarkan hasil penelitian menunjukan bahwa 66,67\% atau disebut sebagian besar dari jawaban sampel sangat setuju dengan kegiatan kepramukaan yang diikuti 
oleh anggota pramuka di sekolah mampu menghasilkan ide-ide yang unik dan menarik dan 33,33\% atau disebut sebagian kecil menjawab setuju dengan pernyataan tersebut. $83,33 \%$ atau disebut pada umumnya dari jawaban sampel sangat setuju dengan kegiatan kepramukaan yang diikuti oleh anggota pramuka di sekolah mengajarkan banyak permainan yang mampu menghasilkan ide-ide yang unik dan menarik dan 16,67\% atau disebut sedikit sekali menjawab setuju dengan pernyataan tersebut. 66,67\% atau disebut sebagian besar dari jawaban sampel sangat setuju dengan permainan dalam kegiatan kepramukaan yang diikuti oleh anggota pramuka di sekolah membuat anggotanya menjadi kreatif dan 33,33\% atau disebut sebagian kecil menjawab setuju dengan pernyataan tersebut.

Berdasarkan hasil penelitian menunjukan bahwa 16,67\% atau disebut sedikit sekali dari jawaban sampel sangat setuju dengan keharusan setiap anggota pramuka harus bisa menghasilkan satu prakarya dan $83,33 \%$ atau disebut pada umumnya menjawab setuju dengan pernyataan tersebut. 83,33\% atau disebut sedikit sekali dari jawaban sampel sangat setuju dengan dukungan dari pihak sekolah harus penuh dan $16,67 \%$ atau sebagian kecil menjawab setuju dengan pernyataan tersebut. 66,67\% atau disebut sebagian besar dari jawaban sampel sangat setuju dengan Lingkungan sekolah harus dimanfaatkan semaksimal mungkin untuk kegiatan kepramukaan dan 33,33\% atau disebut sebagian kecil menjawab setuju dengan pernyataan tersebut.

Berdasarkan hasil penelitian menunjukan bahwa $66,67 \%$ atau disebut sebagian besar dari jawaban sampel sangat setuju dengan pembina pramuka harus memiliki caracara tertentu yang mampu menyalurkan potensi para anggota pramuka dan 33,33\% atau disebut sebagian kecil menjawab setuju dengan pernyataan tersebut. 50,00\% atau disebut setengah dari jawaban sampel sangat setuju dalam pembinaan kegiatan kepramukaan, pembina pramuka harus memberikan kebebasan bagi siswa untuk berkreasi dan $33,33 \%$ atau disebut sebagian kecil menjawab setuju dengan pernyataan tersebut, serta $16,67 \%$ atau disebut sedikit sekali menyebutkan kurang setuju dengan pernyataan tersebut. 50,00 \% atau disebut setengah dari jawaban sampel sangat setuju dengan permainan yang akan dimainkan dalam kegiatan kepramukaan haruslah permainan yang bisa menarik minat pada anggota pramuka dan 16,67\% atau disebut sedikit sekali menjawab setuju dengan pernyataan tersebut, serta 33,33\% atau disebut sebagian kecil lagi menyebutkan kurang setuju dengan pernyataan tersebut.

Berdasarkan hasil penelitian menunjukan bahwa 16,67\% atau disebut sedikit sekali dari jawaban sampel sangat setuju dengan pernyataan para pembina pramuka di sekolah ini sudah menjalankan perannya dengan sangat baik dan 83,33\% atau disebut pada umumnya menjawab setuju dengan pernyataan tersebut. 33,33\% atau sebagian kecil dari pendapat sampel menjawab bahwa program program kegiatan kepramukaan yang dibuat oleh pembina pramuka di sekolah ini sudah sangat baik dan $66,67 \%$ atau sebagian besar mejwab setuju dengan pendapat tersebut.66,67\% atau disebut sebagian besar dari jawaban sampel sangat setuju dengan pembina pramuka selalu berkomunikasi dengan pihak sekolah tentang kegiatan kepramukaan di sekolah ini dan 33,33\% atau disebut sebagian kecil menjawab setuju dengan pernyataan tersebut.

Berdasarkan hasil penelitian menunjukan bahwa 66,67\% atau disebut sebagian besar dari jawaban sampel sangat setuju dengan pembina pramuka selalu bekerjasama dengan pihak sekolah tentang pelaksanaan kegiatan kepramukaan di sekolah ini dan $33,33 \%$ atau disebut sebagian kecil menjawab setuju dengan pernyataan tersebut. 33,33 $\%$ atau disebut sebagian kecil dari jawaban sampel sangat setuju bahwa pembinaan 
pramuka berda dalam kategori sangat baik dan $50.00 \%$ atau disebut setengah menjawab setuju dengan pernyataan tersebut, serta $16,67 \%$ atau disebut sedikit sekali menyebutkan kurang setuju dengan pernyataan tersebut. 50,00\% atau disebut setengah dari jawaban sampel sangat setuju dengan pelatihan pembinaan pramuka berlangsung dengan tertib dan setengahnya lagi atau $50,00 \%$ menjawab setuju dengan pernyataan tersebut.

Berdasarkan hasil penelitian menunjukan bahwa 50,00\% atau disebut setengah dari jawaban sampel sangat setuju dengan metode pembinaan dengan pemberian teori disertai praktek oleh dewan ambalan kepada anggota pramuka sesuai dengan tujuan masing-masing kegiatan dan setengahnya lagi atau 50,00\% menjawab setuju dengan pernyataan tersebut. 50,00\% atau disebut setengah dari jawaban sampel sangat setuju dengan petualangan yang menarik di alam terbuka kegiatan yang diikuti juga dapat meningkatkan keakraban dengan pembina dan anggota pramuka lainnya dan setengahnya lagi atau 50,00\% menjawab setuju dengan pernyataan tersebut. $66,67 \%$ atau disebut sebagian besar dari jawaban sampel sangat setuju dengan game kekompakan bersama anggota pramuka yang diikuti dapat meningkatkan kecerdasan emosional dan 33,33\% atau disebut sebagian kecil menjawab setuju dengan pernyataan tersebut. 66,67\% atau disebut sebagian besar dari jawaban sampel sangat setuju bahwa selain meningkatkan kepercayaan diri, kegiatan outbond yang diikuti dalam kegiatan pramuka juga menumbuhkan rasa keberanian dalam mengambil resiko dan 33,33\% atau disebut sebagian kecil menjawab setuju dengan pernyataan tersebut.

\section{PEMBAHASAN}

Dari hasil penelitian menunjukkan keseluruhan jawaban pernyataan tentang Implementasi Pembinaan Kepramukaan Terhadap Persepsi Kepala Sekolah Di SMP SeKecamatan Baiturrahman Banda Aceh tahun 2016 dapat digambarkan dalam tabel berikut ini:

Tabel Hasil Keseluruhan Jawaban Pernyataan (Angket)

\begin{tabular}{|c|c|c|c|c|}
\hline No & Sangat Setuju & Setuju & Kurang Setuju & Total \\
\hline 1 & 3 & 3 & 0 & 6 \\
\hline 2 & 4 & 2 & 0 & 6 \\
\hline 3 & 3 & 3 & 0 & 6 \\
\hline 4 & 3 & 3 & 0 & 6 \\
\hline 5 & 4 & 2 & 0 & 6 \\
\hline 6 & 6 & 0 & 0 & 6 \\
\hline 7 & 4 & 2 & 0 & 6 \\
\hline 8 & 5 & 1 & 0 & 6 \\
\hline 9 & 4 & 2 & 0 & 6 \\
\hline 10 & 1 & 5 & 0 & 6 \\
\hline 11 & 5 & 1 & 0 & 6 \\
\hline 12 & 4 & 2 & 0 & 6 \\
\hline 13 & 4 & 2 & 0 & 6 \\
\hline 14 & 3 & 2 & 1 & 6 \\
\hline \hline 15 & 3 & 1 & 2 & 6 \\
\hline
\end{tabular}




\begin{tabular}{|c|c|c|c|c|}
\hline 16 & 1 & 5 & 0 & 6 \\
\hline 17 & 2 & 4 & 0 & 6 \\
\hline 18 & 4 & 2 & 0 & 6 \\
\hline 19 & 4 & 2 & 0 & 6 \\
\hline 20 & 2 & 3 & 1 & 6 \\
\hline 21 & 3 & 3 & 0 & 6 \\
\hline 22 & 3 & 3 & 0 & 6 \\
\hline 23 & 3 & 3 & 0 & 6 \\
\hline 24 & 4 & 2 & 0 & 6 \\
\hline 25 & 4 & 2 & 0 & 6 \\
\hline Jumlah & 86 & 60 & 4 & 150 \\
\hline Rata-rata & 3.44 & 2.4 & 0.16 & 6 \\
\hline$\%$ & 57.33 & 40.00 & 2.67 & 100 \\
\hline
\end{tabular}

(Sumber: Hasil Pengolahan Data)

Dari tabel di atas menunjukan bahwa 57,33\% atau lebih dari setengah kepala sekolah menjawab sangat setuju terhadap pembinaan kepramukaan di SMP seKecamatan Baiturrahman Banda Aceh tahun 2016 dan 40,00\% atau kurang dari setengah yang setuju dengan pernyataan tersebut sedangkan sedikit sekali atau hanya 2,67 responden menjawab kurang setuju dengan pernyataan tersebut. Sehingga dapat disimpulkan bahwa pembinaan kepramukaan di SMP se-Kecamatan Baiturrahman Banda Aceh tahun 2016 berdasarkan pendapat beberapa kepala sekolah berlangsung dengan baik.

\section{KESIMPULAN}

Berdasarkan hasil penelitian dan pembahasan, Implementasi Pembinaan Kepramukaan Terhadap Persepsi Kepala Sekolah Di SMP Se-Kecamatan Baiturrahman Banda Aceh tahun 2016 berlangsung dengan baik. Menurut kepala sekolah para anggota pramuka mengikuti kegiatan dengan sukarela dan tidak ada yang membolos. Pembina pun memberikan materi kepramukaan dengan cara yang menyenangkan. Setiap sela-sela materi, pembina meminta anggota pramuka melakukan permainan atau menyanyi bersama untuk mngurangi rasa bosan. Permainan yang paling sering dimainkan adalah permainan yang kreatif. Dalam pemberian materi, pembina juga membentuk kelompok-kelompok kecil siswa untuk mengerjakan tugas. Keberhasilan pembinaan pramuka di SMP se-Kecamatan Baiturrahman Banda Aceh tahun 2016 pun dapat dilihat dari berbagai prestasi dalam bidang kepramukaan. Dari tahun ke tahun, beragam kejuaran berhasil diraih. Dengan demikian, pembinaan kegiatan pramuka di SMP se-Kecamatan Baiturrahman Banda Aceh tahun 2016 terutama dalam kegiatan rutin kepramukaan, dapat dikatakan telah berhasil.

Hal tersebut dapat dibuktikan dari hasil keseluruhan jawaban angket tertutup dengan kepala sekolah di SMP se-Kecamatan Baiturrahman Banda Aceh yang berada pada rata-rata 3,44 dengan persentase sangat setuju yaitu 57,33\%, sehingga dapat dikatakan bahwa pembinaan kegiatan kepramukaan di SMP se-Kecamatan Baiturrahman Banda Aceh Tahun 2016 berlangsung dengan baik. 


\section{DAFTAR PUSTAKA}

Agus Widodo HS. 2003. Ramuan Lengkap Bagi Pramuka Penggalang, Pramuka Penegak, dan Pembina Pramuka. Yogyakarta: Kwartir Daerah XII DIY, 2003.

Donowardojo, LS. dan M. Djauhari. 2005. Pembinaan Latihan Siaga. Klaten: CV. Sahabat

Hadi, Sutrisno, 1992, Metodologo Research II Yogyakarta: Andi Offset, 1991

Moleong, 2004. Metodologi Penelitian Kualitatif. Bandung: PT. Remaja Rosdakarya.Sudarwan Danim, 2004: 145

Undang-undang Republik Indonesia Nomor 20 Tahun 2003 Tentang Sistem Pendidikan Nasional dan Peraturan Pemerintah Republik Indonesia Tahun 2010 Tentang Penyelenggaraan pendidikan Serta Wajib Belajar. Bandung: Citra Umbara, 2010.

Wahyudi. 2009. Kepemimpinan Kepala Sekolah dalam Organisasi Pembelajaran. Bandung: Alfabeta.

Wahjosumidjo. 2005. Kepemimpinan Kepala Sekolah, Tinjauan Teori dan Permasalahannya. Jakarta: Raja Grafindo Persada.

Aqib, Zainal dan Sujak. 2011. Panduan dan Aplikasi Pendidikan Karakter. Jakarta : Gaung Persada Press. 